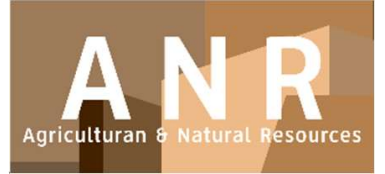

PAPER - OPEN ACCESS

\title{
Pembangunan Demplot Agroforestri Di Kphl Batutegi Lampung (Establishment of Agroforestry Plotsat Cempaka Forestry Partnership in Batutegi Forest Management Unit, Lampung Province)
}

\author{
Author $\quad$ : Danu dan Dona Octavia \\ DOI $\quad: 10.32734 /$ anr.v3i1.832 \\ Electronic ISSN $\quad: 2654-7023$ \\ Print ISSN : :2654-7015
}

Volume 3 Issue 1-2020 TALENTA Conference Series: Agriculturan \& Natural Resource (ANR)

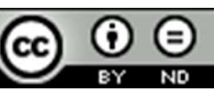

This work is licensed under a Creative Commons Attribution-NoDerivatives 4.0 International License.

Published under licence by TALENTA Publisher, Universitas Sumatera Utara

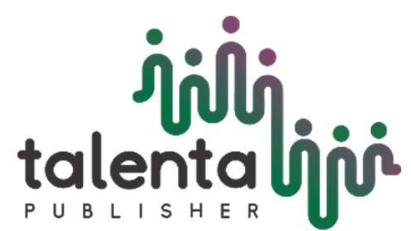




\title{
Pembangunan Demplot Agroforestri Di Kphl Batutegi Lampung (Establishment of Agroforestry Plotsat Cempaka Forestry Partnership in Batutegi Forest Management Unit, Lampung Province)
}

\author{
Danu $^{\mathrm{a}, *}$ dan Dona Octavia ${ }^{\mathrm{b}}$ \\ ${ }^{a}$ Balai Penelitian dan Pengembangan Teknologi Perbenihan Tanaman Hutan Jl. Pakuan Ciheuleut PO. Box 105, Bogor 16001 Telp/Fax: 0251- \\ 8327768, Indonesia \\ ${ }^{b}$ Pusat Penelitian dan Pengembangan Hutan, Jl. Gunung Batu No.5, Bogor Telp. 0251-8633234, Fax. 0251-8638111, Indonesia
}

danu_bptp@yahoo.co.id,donasyifa@gmail.com

\begin{abstract}
Abstrak
Untuk meningkatkan tutupan lahan dan kesejahteraan masyarakat di sekitar hutan melalui pengembangan mata pencaharian, pengelolaan hutan diperlukan termasuk melalui penanaman dengan model agroforestri. Badan Penelitian, Pengembangan dan Inovasi bekerja sama dengan Asian Forest Cooperation Organization (AFoCO) telah membangun demplot Agroforestri di areal Kemitraan Kehutanan Cempaka di bawah Kesatuan Pengelolaan Hutan Lindung (KPHL) Batutegi, Kabupaten Pringsewu, Lampung yang merupakan salah satu skema perhutanan sosial. Area seluas 10 hektar ditanami dengan tanaman kayu yaitu pala (Myristica fragrans), cengkeh (Syzygium aromaticum), champaca (Michelia champaca), kemiri (Aleurites moluccana), resin mata kucing (Shorea javanica), manggis (Garcinia mangostana), maja (Crescentia) cujete), dan pisang (Musa Sp.). Tanaman semak dan tanaman semusim lainnya adalah Lada semak (Piper albi), gamal (Gliricidia sepium), jahe (Zingiber officinale), jahe (Curcuma zanthorrhiza) dan Lemongrass (Cymbopogon nardus). Kegiatan penanaman secara partisipatif dilakukan oleh kelompok tani Kemitraan Kehutanan Cempaka. Jarak tanam antar pohon sejenis adalah 8 mx 8 m (pala-pala, cengkeh-cengkeh), jarak antar pohon (pala-cengkeh) adalah $4 \mathrm{~m}$ x 4m. Persentase pertumbuhan diamati pada usia 1, 6 dan 12 bulan setelah tanam masing-masing 96,18\%; $73,92 \%$ dan $70,17 \%$. Persentase pertumbuhan cukup baik selama 12 bulan setelah tanam, didukung oleh partisipasi masyarakat yang terlihat tinggi dalam memelihara tanaman mereka.
\end{abstract}

Kata Kunci: agroforestri; kemitraan; partisipasi masyarakat; Lampung

\section{Pendahuluan}

Pemerintah melaksanakan pembangunan dan peningkatan kesejahteraan masyarakat tidak lepas dari adanya peran penting hutan. Hutan memiliki fungsi sebagai sebagai pengatur tata air, iklim, udara bersih, menyerap karbon, rekreasi, pendidikan, soisial dan ekonomi [1, 2]. Namun dari luas 187,7 ha, sebesar 50,04\% sudah tidak berhutan [3], sehingga hutan perlu dikelola dan dikembalikan ke fungsi semula. Salah satu pengelolaan hutan yang lestari adalah pengelolaan hutan dalam bentuk perhutanan sosial, salah satunya melalui skema Kemitraan Kehutanan. Perhutanan sosial dianggap mampu menjadi pemicu simpul-simpul pertumbuhan baru wilayah yang terkoneksi dengan infrastruktur, meningkatkan kesejahteraan dan pertumbuhan ekonomi pedesaan serta mengurangi kesenjangan [4]-[5].

Perhutanan Sosial sebagai suatu sistem pengelolaan hutan lestari yang dilaksanakan dalam kawasan Hutan Negara atau Hutan Hak/Hutan Adat berbasis masyarakat yang diatur dalam Peraturan Pemerintah No. 83 Tahun 2016 tentang 
Perhutanan Sosial mengamanatkan 5 (lima) skema yaitu Hutan Kemasyarakatan (HKm), Hutan Desa, Hutan Tanaman Rakyat (HTR) dan Kemitraan Kehutanan dan Hutan Adat, yang dalam implementasinya memerlukan perencanaan yang baik untuk mendukung terlaksananya pengelolaan hutan berbasis masyarakat yang lestari. Prosedur perencanaan ini memiliki peran penting dalam pengelolaan hutan karena merupakan langkah awal dalam memulai pengelolaan hutan [6].

Dalam kerangka kerjasama AFoCO dan implementasi Rencana Pengelolaan Hutan Desa (RPHD) ataupun Rencana Kerja Usaha Izin Usaha Pemanfaatan Hutan Kemasyarakatan (RKUIUPHKm) periode 10 tahun dan Rencana Kerja Tahunan tahun 2017-2018 disepakati untuk membangun demplot agroforestri di ketiga pilot site yang berada di area Perhutanan Sosial yaitu HKM Tuartana di Desa Hikong, Kab.Sikka-NTT, Hutan Nagari Paru di Kab. SijunjungSumatera Barat dan Kemitraan Kehutanan di KPHL Batutegi - Lampung. Implementasi RKT mencakup pembangunan demplot penanaman, kegiatan perlindungan, pencegahan kebakaran, pemanfaatan hasil hutan non kayu, kawasan, jasa lingkungan, dan pengembangan kelembagaan [7].

Potensi sumber daya hutan provinsi Lampung seluas 1.004,7 ha (Surat Keputusan Menteri Kehutanan nomor 784/Menhut-II/2012, terdiri atas hutan konservasi 462,0 ha, hutan lindung 317,6 ha, hutan produksi terbatas 33,4 ha dan hutan produksi 191,7 ha [3]. Sebesar 68,36 \% kawasan tersebut dalam kondisi tidak berhutan dan kritis. KPHL Batutegi bekerjasama dengan AFoCO dan Pusat Litbang Hutan melakukan kegiatan penanaman (plantation)/pengayaan seluas 10 ha di areal Kemitraan kehutanan Cempaka KPHL Batutegi Resort Way Waya Register 22 desa Sumber Bandung, Kecamatan Pagelaran, Kabupaten Pringsewu, Lampung. Berdasarkan hasil musyawarah dengan kelompok tani Cempaka (FGD), jenis yang ditanam adalah pala (Myristica fragrans), cengkeh (Syzygium aromaticum), cempaka (Michelia champaca), kemiri (Aleurites moluccana), damar (Shorea javanica), manggis (Garcinia mangostana), maja (Crescentia cujete), Gliricide (Gliricidia sepium) dan pisang (Musa Sp.) dengan tanaman semusim jahe (Zingiber officinale), temulawak (Curcuma zanthorrhiza), Sereh (Cymbopogon nardus) dan lada perdu (Piper albi).

Kegiatan penanaman dilakukan menggunakan pola partisipasi dan insentif. Diharapkan dengan adanya kegiatan ini dapat meningkatkan kapasitas kelompok tani dalam mengelola hutan, meningkatkan produktivitas hutan, serta sekaligus meningkatkan pendapatan dan kesejahteraan petani. Selain itu, kegiatan penanaman ini tidak hanya berupa penambahan jumlah luas tutupan lahan, namun juga untuk meningkatkan modal sosial kelompok tani sehingga tercapai kemandirian kelompok sebagai faktor pendukung dalam penanaman dan usaha perhutanan sosial selanjutnya. Tujuan kegiatan pembangunan demplot agroforestri adalah untuk menambah jumlah tanaman kehutanan dan tanaman penghasil HHBK sebagai upaya meningkatkan tutupan lahan di areal Kemitraan Kehutanan Cempaka KPHL Batutegi, Pringsewu, Lampung. Kegiatan ini juga bertujuan untuk memberdayakan masyarakat dan meningkatkan partisipasi masyarakat dalam penanaman untuk menjamin kelestarian pemanfaatan hasil hutan non kayu.

\section{Metode Penelitian}

\subsection{Waktu dan Lokasi}

Pembangunan demplot agroforestri dilaksanakan di areal Kemitraan Kehutanan Cempaka wilayah KPHL Batutegi - Resort 22 - Way Waya, Desa Sumber Bandung, Kecamatan Pagelaran Utara, Kabupaten Pringsewu, Propinsi Lampung seluas 10 hektar dengan waktu penanaman tanggal 15 - 20 Januari 2018.

Pembangunan demplot agroforestri di areal Kemitraan Kehutanan Cempaka dilakukan dengan pola kerjasama partisipatif antara kelompok tani Cempaka, KPHL Batutegi dan AFoCO Paroject Compenent 3. KPHL Batutegi menyediakan lahan seluas 10 ha dan AFoCO Project membantu menyediakan bibit, pupuk, ajir, herbisida, pestisida dan tanaman pelindung. Sedangkan kelompok tani berperan dalam kegiatan penanaman dengan menanam dan memelihara tanaman hasil penanaman. Pola kerjasama ini telah diikat dalam Nota Kesepakatan Kerjasama. 


\subsection{Teknik Penanaman}

Pola tanam yang digunakan adalah pola agroforestri. Sebagai tanaman pokok digunakan tanaman yang mempunyai tajuk lebar dan batang yang tinggi seperti tanaman pala. Tanaman pengisi yang digunakan adalah tanaman cengkeh dan pisang. Di sekeliling demplot dan baris ke tujuh ditanami tanaman kehutanan seperti damar mata kucing, cempaka, maja, kemiri dan manggis. Jarak tanam antara pohon sejenis yaitu $8 \mathrm{~m}$ x $8 \mathrm{~m}$ (pala-pala, cengkeh-cengkeh). Sementara jarak antar pohon (pala - cengkeh) adalah $4 \mathrm{~m}$ x $4 \mathrm{~m}$. tanaman kehutanan ditanam di sekeling lokasi pada setiap $50 \mathrm{~m}$. Lubang tanam berukuran $40 \mathrm{~cm}$ x $40 \mathrm{~m}$ x $40 \mathrm{~m}$. Pupuk yang digunakan pada penanaman ini adalah pupuk kandang sebanyak 500 gram. Untuk mengurangi penguapan dan terik matahari, tanaman diberi naungan dan mulsa. Naungan menggunakan tanaman gamal dan pisang. Sebelum gamal dan pisang tumbuh besar, naungan sementara dibuat dengan menggunakan bahan alami setempat seperti daun alang-alang, daun kelapa dan daun aren, sedangkan mulsa menggunakan pelepah pisang, alang-alang kering, dan rumput kering.

\subsection{Pengumpulan Data}

Data pertumbuhan tanaman dikumpulkan berdasarkan hasil pengukuran di semua plot kelompok tani. Sedangkan data partisipasi kelompok tani dikumpulkan berdasarkan wawancara dan pengamatan terhadap kelompok dan petani.

\subsection{Pengumpulan Data}

Data pertumbuhan dan informasi yang diperoleh dianalisis secara deskriptif-kualitatif.

\section{Hasil dan Pembahasan}

\subsection{Pertumbuhan Tanaman Pada Demplot}

Kondisi pertumbuhan tanaman agroforestri di areal demplot penanaman kemitraan kehutanan Cempaka-KPHL Batutegi di Kabupaten Pringsewu, Provinsi Lampung berlangsung cukup baik (Tabel 1).

Tabel 1. Kondisi pertumbuhan tanaman umur 12 bulan demplot Agroforestri di KPHL Batutegi, Pringsewu, Lampung (Februari 2018 - Februari 2019).

\begin{tabular}{|c|c|c|c|c|c|c|c|c|}
\hline \multirow{2}{*}{ No. } & \multirow[b]{2}{*}{ Jenis tanaman } & \multicolumn{2}{|c|}{ Jumlah tanaman hidup } & \multicolumn{3}{|l|}{$\%$ hidup } & \multirow{2}{*}{$\begin{array}{l}\text { Diameter } \\
(\mathrm{mm})\end{array}$} & \multirow{2}{*}{$\begin{array}{l}\text { Tinggi } \\
(\mathrm{cm})\end{array}$} \\
\hline & & $\begin{array}{l}\text { Awal } \\
\text { tanam }\end{array}$ & 12 bulan & 1 bulan & 6 bulan & 12 bulan & & \\
\hline 1 & Pala & 1073 & 739 & 94,11 & 79,26 & 68,87 & 7 & 50 \\
\hline 2 & Cengkeh & 746 & 497 & 93,03 & 63,84 & 66,62 & 5 & 42 \\
\hline 3 & Cempaka & 214 & 135 & 94,01 & 75 & 63,08 & 7 & 63 \\
\hline 4 & Damar & 220 & 190 & 94,95 & 75,43 & 86,36 & 8 & 66 \\
\hline 5 & Maja & 311 & 227 & 97,19 & 80,66 & 72,99 & 9 & 54 \\
\hline 6 & Manggis & 34 & 32 & 100 & 80,56 & 94,12 & 9 & 45 \\
\hline 7 & Kemiri & 27 & 22 & 100 & 37,93 & 81,48 & 13 & 93 \\
\hline & Jumlah & 2625 & 1842 & 96,18 & 73,92 & 70,17 & & \\
\hline
\end{tabular}

Secara keseluruhan rata-rata kondisi pertumbuhan demplot pada umur 12 bulan setelah tanam adalah 70,17\%. Rata rata persen tumbuh di plot demplot contoh adalah sebesar $65,75 \%$, plot penelitian sebesar $72,44 \%$ dan kelompok tani sebesar 73,97\% (cempaka putih 64,05\%, cempaka kuning 69,44\%, cempaka asih 69,37\%, Cempaka Agung 70,63\%, Galih Cempaka 70,26\%, Cempaka Madu 85,20\%). Pengamatan awal yaitu umur 1 bulan menghasilkan persentase tumbuh sebesar $96,18 \%$, setelah umur 6 bulan persentase tumbuh mengalami penurunan menjadi $73,9 \%$. Penurunan 
persentase tumbuh terjadi karena kekeringan yang cukup panjang. Hasil ini masih tergolong karena anggota kelompok menjaga dengan sungguh-sungguh area lahan garapannya. Agroforestri merupakan pola pertanian yang diterapkan secara luas di semua wilayah dengan luasan yang bervariasi di setiap wilayah [8].

Tingginya persentase tumbuh tanaman disebabkan karena kesadaran anggota kelompok tani dalam pemeliharaan yang baik seperti pembabatan gulma, penanaman tanaman naungan dan penyulaman, bahkan ada beberapa petani yang mau mengadakan sendiri bibit sulamannya.

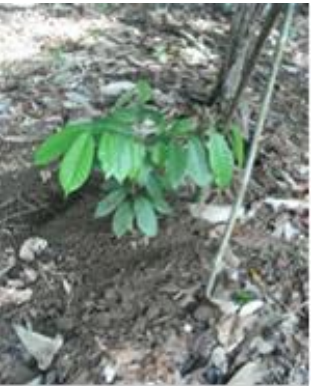

Pala

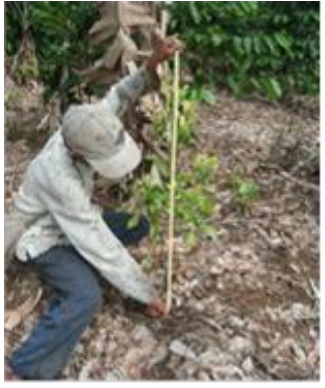

Cengkeh

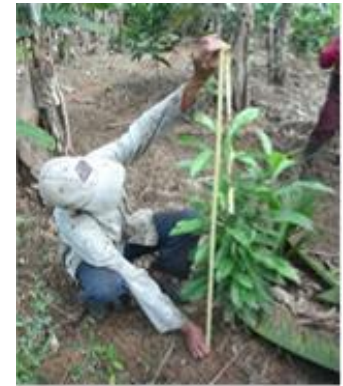

Мaja

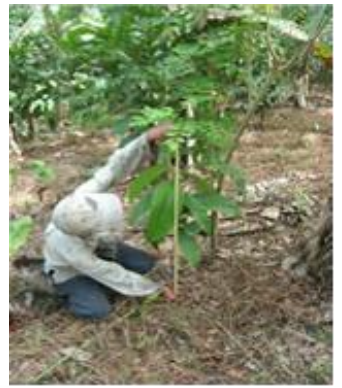

Damar

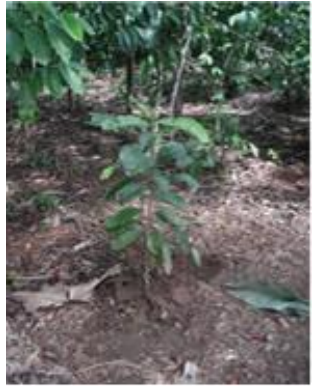

Cempaka

Gambar 1. Pengukuran Tanaman umur 12 bulan

\subsection{Tingkat Partisipasi masyarakat}

Partisipasi kelompok tani Cempaka pada saat evaluasi bulan Februari 2019 cukup meningkat. Hal ini dicirikan dengan kondisi demplot penanaman yang baik. Demplot penanaman terlihat lebih terawatt. Bila terdapat tanaman yang mati, petani segera melakukan penyulaman dengan bibit yang dibeli secara pribadi.

Untuk meningkatkan semangat kelompok tani hutan dilakukan pemberian insentif berupa uang tunai dan kambing. Pemberian insentif dilakukan sesuai kesepakatan. Setelah 4 bulan, dari 12 ekor kambing indukan sudah melahirkan 9 ekor. Sesuai dengan kesepakan antar anggota kelompok tani, setiap pemelihara kambing selama 2 tahun berkewajiban menyerahkan 3 ekor anak kambing siap beranak di tahun kedua dan 1 ekor di tahun ketiga.

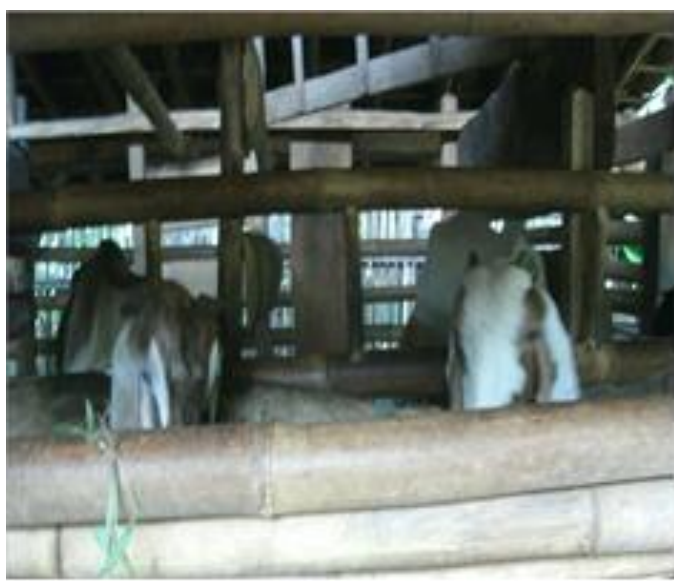

Kandang kambing

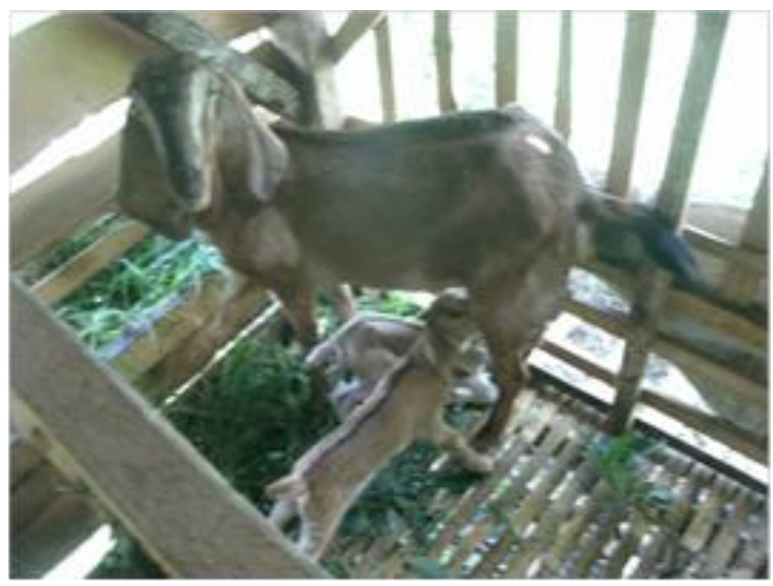

Induk kambing dan 2 ekor anaknya

Gambar 2. Bantuan kambing sebagai modal bergulir dalam rekayasa social.

Anggota kelompok tani Kemitraan Kehutanan Cempaka di KPHL Batutegi, Pringsewu umumnya sudah mengetahui dan mampu melakukan teknik penanaman dengan model agroforestri, pemetaan posisi tanaman dengan GPS, pemeliharaan dan evaluasi pertumbuhan tanaman. Jumlah kelompok tani yang terlibat dalam kegiatan ini sebanyak 6 kelompok yaitu I. Cempaka putih (Ketua: Pak Dimas), II. Cempaka Kuning (Ketua: Sunarya), III. 
Cempaka Asih (Ketua: Pak Arif), IV. Cempaka Agung (Ketua: pak Sudarmawan), V. Galih Cempaka (Pak Imron), VI. Cempaka Madu (Ketua: Pak Arif).

Kelembagaan kelompok tani Cempaka dinilai sudah mulai kuat. Semua kegiatan dilakukan oleh kelompok tani yang dipimpin oleh ketua kelompok tani dan dikoordinir oleh Ketua Gapoktan (Pak Dimas). Pendamping dan bimbingan teknis di lapangan dilakukan oleh Koordinator lapangan dari KPHL Batutegi. Untuk menjaga dan menguatkan kelembagaan kelompok tani, dilakukan pertemuan-pertemuan rutin antara anggota kelompok tani, ketua kelompok tani, ketua gabungan kelompok tani, dan kordinator lapangan. Pertemuan ini bertujuan untuk menjaga komunikasi antar kelompok tani sehingga kegiatan agroforestry dapat berjalan dengan baik. Seluruh rencana program, pembiayaan, pelaksanaan kegiatan, dan evaluasi kegiatan dilaporkan dalam berita acara dan selalu dimusyawarahkan terlebih dahulu.

\section{Kesimpulan}

Pembangunan demplot agroforestri dapat meningkatkan tutupan lahan hutan seluas 10 ha di KPHL Batutegi Lampung dengan tanaman komersial dan pengkayaan jenis seperti pala, cengkeh, cempaka, damar, maja, manggis, dan kemiri. Tanaman pisang ditanam diantara pohon-pohon untuk memenuhi kebutuhan jangka pendek.

Kelembagaan kelompok tani Cempaka masih perlu penguatan dengan cara memperbanyak kegiatan pertemuan kelompok dan antar kelompok yang dipimpin oleh Ketua Gapoktan dengan agenda yang jelas. Kelompok tani Cempaka berpotensi untuk ditingkatkan dari kelompok tani Pemula menjadi Kelompok Tani Madya.

\section{Ucapan Terima Kasih}

Ucapan terimakasih kepada AFoCO Regional Project Component 3 "Facilitating the Participatory Planning of Community Based Forest Management using Geographic Information System and Remote Sensing Technologies in Forest Resource Management in the Philippine, Indonesia and Thailand" yang telah mendanai kegiatan penelitian dan pendampingan pada Hutan Kemitraan Cempaka, Batutegi, Pringsewu, Lampung dan kepada masyarakat Desa Sumberbandung yang mengikuti dalam pelaksanaan kegiatan penelitian dan pendampingan.

\section{Referensi}

[1] Suryanto (2012) "Hutan sebagai sumberdaya dunia." Info Teknis Diperokarpa 6 (1): 59-75.

[2] Massiri, S.D., B. Nugroho, H. Kartodihardjo, \& R. Soekmadi (2016) "Preferensi dan motivasi masyarakat lokal dalam pemanfaatan sumberdaya hutan di Taman Nasional Lore Lindu, Provinsi Sulawesi Tengah.” Jurnal Manuasi dan Lingkungan 23 (2): 215 - 223.

[3] Statistik Lingkungan Hidup dan Kehutanan Tahun (2017)

[4] Suharti, S., Ginoga, K.L., Murniati, Octavia, D., \& Windyoningrum, A. (2017) “Langkah strategis menuju percepatan realisasi capaian program perhutanan sosial”, Policy Brief Volume 11 (08), Pusat Penelitian dan Pengembangan Sosial, Ekonomi, Kebijakan dan Perubahan Iklim, BLI Kementerian Lingkungan Hidup dan Kehutanan

[5] Tarigan, A. (2018) "Prolog TORA dan PS: Kebijakan Negara atau Jokowi ?. Bunga Rampai: Strategi Tora dan Perhutanan Sosial. Seri: Penguatan Pranata dan Prakarsa Lokal dalam Penyiapan Dokumen dan Perijinan. Konsorsium KpSHK", IPB Press Printing, Bogor

[6] Peraturan Menteri Lingkungan Hidup dan Kehutanan Republik Indonesia Nomor P.83/MENLHK/SETJEN/KUM.1/10/2016 tentang Perhutanan Sosial

[7] Peraturan Direktur Jenderal Perhutanan Sosial dan Kemitraan Lingkungan Nomor P.16/PSKL/SET/PSL.0/12/2016 tentang Pedoman Penyusunan Rencana Pengelolaan Hutan Desa, Rencana Kerja Usaha Izin Usaha Pemanfaatan Hutan Kemasyarakatan dan Rencana Kerja Usaha Izin Usaha Pemanfaatan Hasil Hutan Kayu Hutanan Tanaman Rakyat

[8] Zomer, R.J., Trabucco, A., Coe, R., Place, F. (2009) “Trees on farm: analysis of global extent and geographical patterns of agroforestry", Bulletin ICRAF Working Paper - World Agroforestry Centre 2009 No.89 pp.63 pp. ref. 30. 